\title{
6-(2,3-Dichlorodiphenyl)-1,2,4-Triazine-3,5-Diamine Use in Pregnancy and Body Stalk Anomaly- A Possible Association?
}

\author{
ANCA HUNIADI ${ }^{1,2}$, ANDREA SORIAN ${ }^{2}$, ADRIAN MAGHIAR ${ }^{1,2}$, DIANA MOCUTA ${ }^{1}$, LIANA ANTAL ${ }^{1,2}$, OVIDIU LAUREAN POP1, $^{1}$ \\ CLAUDIA TEODORA J UDEA PUSTA ${ }^{1 *}$, CAMELIA LIANA BUHAS ${ }^{1 *}$, ANDREI PASCALAU ${ }^{1}$, MIRCEA SANDOR ${ }^{1}$ \\ 'University of Oradea, Faculty of Medicine and Pharmacy, 10, 1 Decembrie Sq., 410073, Oradea, Romania. \\ 2Pelican Hospital Oradea, 2 Corneliu Coposu Str., 410450, Oradea, Romania
}

\begin{abstract}
Body Stalk Anomaly is a rare malformation syndrome characterized by anterior abdominal wall defect, kyphoscoliosis, limb reduction, rudimentary umbilical cord, craniofacial defects and anomalies of the chest wall. The association between antiepileptic drugs, such as Lamotrigine [6-(2,3-dichlorophenyl)-1,2,4-triazine3,5-diamine], and the development of such malformation have been studied for many years. Many studies can be found regarding the teratogenic potential of Lamotrigine, but they have contradictory results. We present the case of a 34-year old pregnant, caucasian woman, known with acquired epilepsy due to neurocysticercosis for which she is under treatment with Lamotrigine $400 \mathrm{mg} /$ day. The patient was examined at 12 weeks of gestational age, when the ultrasound images showed a large defect in the fetal abdominal wall: eviscerated liver and bowel outside the coelomic cavity, kyphoscoliosis, a short umbilical cord, nuchal translucency $2.8 \mathrm{~mm}$, mandibular retrognathism. Based upon the aforementioned ultrasound findings we considered the diagnosis to be Body Stalk Anomaly and recommended a medical abortion. Embryological remainings were sent to pathology and genetic department revealing Turner Syndrome. We consider important to detecttypical features of the anomaly in the first trimester and distinguish itfrom other abdominal defects like omphalocele and gastroschisis, since the conditions imply different management. Another important issue is to be aware about the treatment with Lamotrigine.
\end{abstract}

Keywords: body stalk anomaly, amniotic band sequence, Turner Syndrome, Lamotrigine

Body Stalk Anomaly, also called Limb Body Wall complex, is a rare anomaly characterized by anterior abdominalwall defect, kyphoscoliosis, limb reduction, rudimentary umbilical cord, craniofacial defects and anomalies of the chest wall [1]. This rare malformation syndrome has an estimated incidence of 1/14.000 to $1 /$ 31.000 pregnancies worldwide. However, in a more recent multicentre study by Daskalakiset al. in which 106,727 foetuses between 10 and 14 weeks of gestation were analysed, an incidence of $1 / 7,500$ pregnancies were found [2].

This anomaly is massively disfiguring and lethal, with malformations of the thorax and/or the abdomen and often with limb defects. The intrathoracic and abdominal organs lie outside the abdominal cavity and are contained within a sac made of amnioperitoneal membrane that is directly attached to the placenta. The umbilical cord may be totally absent or extremely shortened. Severe kyphoscoliosis is often present.

Two main phenotypes have been described in the literature as follows: first, foetuses with craniofacial defects that show two specific characteristics, namely, exencephaly always associated with facial clefts and amniotic bands between the cranial defect and placenta; second, foetuses without craniofacial defects often showing urogenital anomalies, anal atresia, lumbosacral meningoceles, and placental anomalies characterized by the presence of short cord, persistence of extraembryonic coelom, and intact amnion [3,4].

The lack of a consensus regarding the etiology of body stalk anomaly, as well as the varied phenotypes, has led to a confusing array of synonyms, including amniotic band sequence, short umbilical cord syndrome, early amnion rupture sequence, and limb-body wall complex. Limb-body wall complex may be considered the primary diagnosis in cases in which anomalies of the extremities coexist. For practical purposes, both body stalk anomaly and limb-body wall complex are generally associated with a normal karyotype and share a similarly unfavourable prognosis [5].

The association between between antiepileptic drugs, like Lamotrigine, and the presence of such malformation have been studied for many years. The animal studies point out that the administration of Lamotrigine, in different doses, may induce different kind of malformation in mice: reduction in body weight, cranio-facial malformation, delayed intrauterine growth, or even embryonic resorption $[6,7]$.

Lamotrigine's chemical compositions is $6-(2,3-$ dichlorophenyl) -1,2,4-triazine-3,5-diamine, having a molecular mass of $256.091 \mathrm{~g} / \mathrm{mol}$ [8]. Despite that the chemical formula is a simple one, $\mathrm{C}_{0} \mathrm{H}_{7} \mathrm{C}_{1} \mathrm{~N}_{5}$, the pharmaco-dynamics of this drug is not well understood (fig. 1) $[8,9]$.<smiles>Nc1nnc(-c2cccc(Cl)c2Cl)c(N)n1</smiles>

Fig. 1.Lamotrigene. Structural formula

It seems to interfere with the Na channel. One of the hypotheses is that Lamotrigineinterferes with the neuronal sodium channels and this results in the inhibition of the release of glutamate and aspartate $[9,10]$. It is metabolised primarily in the liver by uridine-diphosphate glucuronosyl transferase 1A4 (UGT1A4) to LTG 2-N-glucuronide [11]. Other antiepileptic drugs are cleared by the kidneys through 
cytochrome P450 system. The clearance of (UGT1A4) is directly related with the oestrogen level [12-15].

The aim of this paper isto highlight the importance of establishing a safety dose for Lamotrigine during pregnancy. Also, it is important to detect typical features of the congenital anomaly in the first trimester and distinguish it from other abdominal defects like omphalocele and gastroschisis, since the conditions imply different management.

\section{Experimental part}

We present the case of a 34-year-old, pregnant, caucasian woman, with known acquired epilepsy due to the neuro-cysticercosis for which she is under treatment with $400 \mathrm{mg} /$ day. The patient is pregnant for the first time, and the first prenatal visit was performed at 5 weeks of gestation, when the pregnancy was confirmed in utero; the patient was prescribed folic acid.

At the second medical visit, the pregnancy was 10 weeks old, the ultrasound exam revealed an abnormal conformation of the inferior body of the embryo in the coelomic space and a short umbilical cord. The patient was rescheduled at 12 weeks of gestational age for another visit when the ultrasound images showed a large abdominal wall defect consisting of an eviscerated liver and bowel outside the coelomic cavity, kyphoscoliosis, a short umbilical cord, nuchal translucency $2.8 \mathrm{~mm}$, and mandibular retrognathism (figs.2, 3a, 3b).

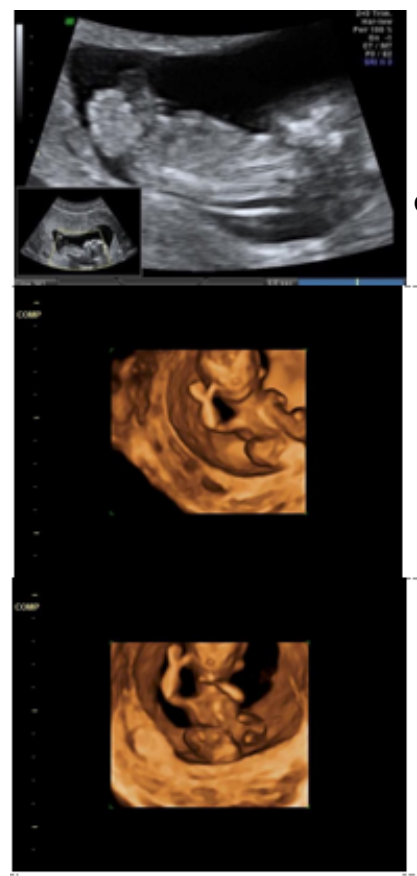

Fig. 2.Ultrasound $2 \mathrm{~d}$ revealing a 12 weeks embrio with

kyphoscoliosis, increased nuchal translucency, large abdominal defect consisting of an eviscerated liver and bowel outside the coelomic cavity

Fig. 3a. Ultrasound $4 d$ imagines revealing the 12 weeks embrio the large abdominal defect and kyphoscoliosis and normal face, torax and upper limbs

Fig. 3b. Ultrasound $4 d$ imagines revealing the 12 weeks embrio the large abdominal defect and kyphoscoliosis and normal face, torax and upper limbs

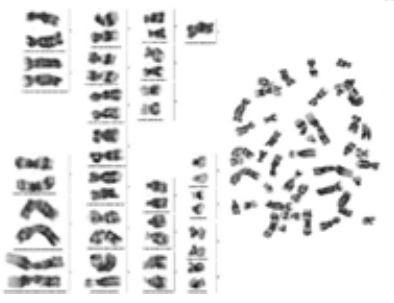

Fig. 4. The genetic exam showed foetal aneuploidy, chromosomal abnormality, and total monosomy $x$ homogeneous, revealing

Turner Syndrome

\section{Results and discussion}

Based on the ultrasound findings, we considered the diagnosis to be Body Stalk Anomaly, and we recommended termination of the pregnancy; however, the patient refused our recommendation. At 14 weeks of gestation, the patient accepted termination of the pregnancy. Medical abortion was induced using an intravaginal single dose of Misoprostol $(600 \mathrm{mg})$.
Embryological remains were sent to the Pathology Department for an autopsy and genetic analysis. The dissection showed a female foetus with an abdominal defect resulting in evisceration of the bowel and liver connected directly to the smaller umbilical cord $(1 \mathrm{~cm}$ long) and a normal placenta. The limbs were shortened, and the spine presented kyphoscoliosis. There were no other major malformations of the internal organs on gross examination.

Genetic analysis from the placenta revealed foetal aneuploidy, chromosomal abnormality, total monosomy $X$, and Turner Syndrome (fig. 4). The karyotype of both parents was done, showing normal results.

Body stalk anomaly is a term used to describe a pattern of severe defects that, in most of the reported cases, is incompatible with life. This condition should be suspected when a large abdominal wall defect is observed in addition to abnormalities of the axial skeleton, such as kyphosis or scoliosis, and a short or absent umbilical cord [16]. Body stalk defects can be detected by ultrasound at the end of the first trimester of pregnancy. In our case, the detection was done at 9 weeks +4 days of gestation and then reconfirmed at 12 weeks. The ultrasound images were related to those reported in the literature.

An appropriate midsagittal view of the foetus for measuring the crown-rump length, together with measuring the nuchal translucency and adequate sweeps through the head and abdomen, should identify all cases of body stalk anomaly between 11 and 13 weeks of gestation. Before establishing a final diagnosis, it is important to consider other pathologies that affect the abdominal wall, such as the omphalocele, gastroschisis, vesical exstrophy, Cantrell pentalogy (complete form requires demonstration of a supraumbilical wall defect, a lower sternal defect, a deficiency of the anterior diaphragm and the diaphragmatic pericardium; an intracardiac defect and incomplete forms of this disorder are also recognized and may present a diagnostic challenge), amniotic band syndrome, Beckwith-Wiedemann Syndrome, and the OEIS complex (omphalocele, exstrophy of cloaca, imperforate anus, and spinal defects) [17]. Sonographic features of cloacal exstrophy and the more severe OEIS complex include an absentfoetal bladder, a sub-umbilical abdominal wall defect, spinal distortion, and a sacral myelomeningocele [5]. In these conditions, the herniated abdominal wall contents are covered by a membrane and are not directly attached to the placenta, as occurs in body stalk anomaly and the limb-body wall complex. The prognosis of the bodystalk complex is very poor compared to isolated exomphalos or gastroschisis $[5,18]$.

It has not yet been determined if teratogenic factors are involved in the pathology of body stalk anomaly. In our case report, we observed only one associated risk factor, a possible teratogen - Lamotrigine ( $400 \mathrm{mg} / \mathrm{day}$ ). Lamotrigine teratogenicity has been proved in animals, but regarding its effects on humans is still controversial. In accordance with the results released by EURAP group a daily dose below $300 \mathrm{mg}$ is associated with the lowest malformation rate [19].

Recent studies are focusing not only on the malformations induced bysecond generation antiepileptic medication but also on the neurodevelopmental disturbances in children exposed to Lamotrigine in utero [20]. However, in some case series, it has been reported that $50 \%$ of women with foetuses affected by body stalk anomaly smoke cigarettes or drink alcohol, and 30\% smoked marijuana [16,21]. It is also important to consider the fact that alcohol and drug consumption by pregnant 
women can be associated with an increase suicide risk rate [22,23] and favor homicides [24].

Three major theories have been proposed to explain the origin of the main phenotypic features that are found in body stalk anomaly. The first and most accepted theory is an early rupture of the amnion before there is an obliteration of the coelom. Abdominal, spinal, and limb defects could then be explained by passage of the lower part of the foetus into the extraembryonic coelom, resulting in an extreme form of the amniotic band sequence [2].

Another theory suggests an abnormal folding of the trilaminar disc in its cephalic, caudal, and lateral directions that might lead to persistence of the coelomic cavity. After gastrulation, the embryo consists of a trilaminar germinal disk. As the embryo grows, the disk curves. It is transformed into a cylindrical foetus by circumferential folding. This process results in separation of the intraembryonic and extraembryonic cavities and formation of the body stalk (umbilical cord). The amniotic cavity, initially located dorsal to the germinal disk, grows rapidly to encircle the foetus and obliterate the extraembryonic coelom [5].

Van Allen etal. proposed that a vascular compromise in early gestational weeks might cause inadequate closure of the abdominal wall as well as instability of the amnion that then undergoes early rupture [21]. Some authors consider that the compromise of embryonic blood flow during the first 4 to 6 weeks of gestation leads to failure of closure of the ventral wall and persistence of the coelomiccavity [5]. Vascular disruption theory is supported by the finding that cocaine abuse may increase the risk of body stalk anomaly $[17,25,26]$.

In the international literature, there are some case reports about Body Stalk Anomaly [5,16,18,27]. Most of the cases are characterized by severe abdominal defects, kyphoscoliosis, abnormalities of umbilical cord, variable presence of limb malformations and of cranio-facial defects [28]. Most of the cases have an enlarged nuchal translucency measurement with a normal karyotype.

The examination of foetal anatomy is important at the time of routine first-trimester nuchal translucency screening and the role of 3D sonography in the evaluation of defects at this early gestational age [29]. Abortion is an extreme measure that must be used in these cases [30].

For our patient, we suspected the diagnosis of BSS at 9 weeks+ 4 days gestation based on ultrasound examination, which was confirmed at 12 weeks of gestation. At that time, we recommended termination of the pregnancy, but the patient refused the option. Finally, termination was induced by PG at 14 weeks gestation, and the pathology exam revealed the eviscerated liver and bowel outside the coelomic cavity, kyphoscoliosis, a shortumbilical cord, and mandibular retrognathism. Genetic examination demonstrated foetal aneuploidy, chromosomal abnormality, and total monosomy $X$ homogeneous, revealing Turner Syndrome.

All of the malformations found in our case could represent non chromosomal anomalies (side effects) related to Lamotrigine administration [31]. This is the first case report on a possible association between body stalk syndrome and Lamotrigine administration, as chromosomal anomaly.

\section{Conclusions}

Body stalk anomaly is a malformation syndrome in which the exact pathophysiology and etiologyremain unknown. Much remains to be elucidated in terms of its real epidemiology, global distribution, and risk factors. Additional efforts should focus on making an early diagnosis to avoid complications for the mother during the pregnancy and/or childbirth. We concluded that it is important to establish a safety dose for Lamotrigine during pregnancy.

\section{References}

1.MANN, L., FERGUSON-SMITH, M., DESAI, M., GIBSON, A., RAINE, P.

Prenat. Diagn., 4, 1984, p.427.

2.DASKALAKIS, G., SEBIRE, N., JURKOVIC, D., SNIJ DERS, R., NICOLAIDES, K. Ultrasound Obstet. Gynecol., 10, 1997, p.416.

3.RUSSO, R., D'ARMIENTO, M., ANGRISANI, P., VECCHIONE, R. Am. J . Med. Genet., 47, 1993, p.893.

4.DERUELLE, P., HAY, R., SUBTIL, D.J Gynecol. Obstet. Biol.Reprod., 29, 2000, p. 385.

5.MURPHY, A., PLATT, L. J., Ultrasound Med., 30, 2011, p.1739.

6.MARCHI, N.S., AZOUBEL, R., TOGNOLA, W.A. Arq Neuropsiquiatr., 59, 2001, p.362.

7.CHANDRANATH, S.I. Birth Defects Res. B. Dev. Reprod. Toxicol., 68, 2003, p.428.

8.***www.sigmaaldrich.com/catalog/product/sigma//3791 (accesed in 15.04.2019).

9.TIERNY, L.M. JR., MCPHEE, S.J., PAPADAKIS, M.A. Current Medical Diagnosis and Treatment. 45th ed. Lange Medical Books. McGrawHill, New York, 2006.

10.DIACONU, C.C., ARSENE, D., PARASCHIV, B., BALACEANU, A., BARTOS, D., Acta Endocrinologica, IX, no. 4, 2013, p. 637-642.

11.BALACEANU, A., DIACONU, C., ARON, G., Medical Ultrasonography, 16, no 2, 2014, p. 172-174.

12.PRAKASH, PRABHU, L.V., NASAR, M.A., RAI, R., MADHYASTHA, S., SINGH, G. Singapore Med. J., 48, nr.10, 2007, p. 883.

13.CHEN, H., YANG, K., CHOI, S., FISCHER, J.H., JEONG, H. Drug Metab. Dispos., 37, 2009, p.1841.

14.ABDEL-DAIM, M.M., ABO-EL-SOOUD, K., ALEYA, L., BUNGAU, S.G., NAJDA, A., SALUJA, R., Oxid. Med. Cell. Longev, 2018, 2018, ID 6276438. https://doi.org/10.1155/2018/6276438

15.ABDEL-DAIM, M.M., ZAKHARY, N.I., ALEYA, L., BUNGAU, S.G., BOHARA, R.A., SIDDIQI, N.J ., Oxid. Med. Cell. Longev.,2018, 2018, ID 2098123. https://doi.org/10.1155/2018/2098123

16.DIACONU, C.C., ARSENE, D., BALACEANU, A., BARTOS, D., Romanian J ournal of Morphology and Embryology, 55, no. 3, 2014, p. 973-976.

17.QUIJANO, F., REY, M., ECHEVERRY, M., AXT-FLIEDNER, R. Case Rep. Obstet. Gynecol., 35, 2014, p.72.

18.KOCHERLA, K., KUMARI, V., KOCHERLA, P. Indian J. Radiol. Imaging, 25, 2015, p.67.

19.TOMSON, T., BATTINO, D., BONIZZONI, E., CRAIG, J., LINDHOUT D., SABERS, A., PERUCCA, E., VAJDA, F.; EURAP STUDY GROUP. Lancet Neurol., 10, nr.7, 2011, p. 609.

20.REIMERS A., BRODTKORB E.Expert Rev.Neurother., 12, nr.6, 2012, p.707.

21.VAN ALLEN M., CURRY C., GALLAGHER L. Am J Med Genet., 28 , 1987, p.529.

22.J UDEA-PUSTA, C., RUSU, A., CAMARASAN, A., Aggress. Violent Behav.,47, 2019, p.68. https://doi.org/10.1016/j.avb.2019.03.006

23.MIHALACHE, G., BUHAS, C., RAHOTÃ, D., Rom. J. Leg. Med., 19, nr. 1, 2011, p. 69

24.BUHAS, C., Aggress. Violent Behav., 18, 2013, p. 434

25.VISCARELLO, R., FERGUSON, D., NORES, J., HOBBINS, J. Obstet. Gynecol., 80, 1992, p.523.

26.JURCA, C., BEMBEA, M., PALLAG, A., MURESAN, M., SZILAGYI, A., BALMOS, A., POP, O., JURCA, A., DOBJANSCHI, L. Farmacia, 66, 2018, p. 216.

27.SMRCEK, J., GERMER, U., KROKOWSKI, M. Ultrasound Obstet. Gynecol., 21, 2003, p.322.

28. PARASCHIV, B., TOMA, C.L., DIACONU, C. Archivos de Bronconeumología, 49, no. 7, 2013, p. 315-316.

29.JUDEA-PUSTA, C., JUDEA, A., NEGRUTIU, B.M., Proceedings of the 35th Balkan Medical Week; 2018, p. 566. Filodiritto Publisher, Editor Diaconu, C. 
30.STOICESCU, M., BUNGAU, S.G., TIT, D.M., MUTIU, G., PURZA, A.L., IOVAN, V.C., POP, O.L. Rom. J. Morphol. Embryol., 58, nr.4, 2017, p.1429.

31.DOLK, H., WANG, H., LOANE, M., MORRIS, J., GARNE, E., ADDOR, M.C., ARRIOLA, L., BAKKER, M., BARISIC, I., DORAY, B., GATT, M., KALLEN, K., KHOSHNOOD, B., KLUNGSOYR, K., LAHESMAA-
KORPINEN, A.M., LATOS-BIELENSKA, A., MEJ NARTOWICZ, J.P., NELEN, V., NEVILLE, A., O'MAHONY, M., PIERINI, A., RIBMANN, A., TUCKER, D., WELLESLEY, D., WIESEL, A., DE JONG-VAN DEN BERG, L.T.W. Neurology, 86, no.18, 2016, p.1716.

$\overline{\text { Manuscript received: } 18.11 .2018}$ 